\title{
Synergistic effect of microbe-associated molecules on human monocyte-derived dendritic cell maturation in vitro
}

\author{
L. M. Skivka, Yu. V. Shvets, N. M. Khranovska ${ }^{1}$, O. G. Fedorchuk², \\ V. V. Pozur, N. V. Senchilo
}

Educational and Scientific Center «Institute of Biology», National Taras Shevchenko University of Kyiv 64/13, Volodymyrska Str., Kyiv, Ukraine, 01601

${ }^{1}$ National Cancer Institute

33/43, Lomonosova Str., Kyiv, Ukraine, 03022

${ }^{2}$ R. E. Kavetsky Institute of Experimental Pathology, Oncology and Radiobiology, NAS of Ukraine 45, Vasilkivska Str., Kyiv, Ukraine, 01022

realmed@i.com.ua

\begin{abstract}
Microbe-associated molecules (MAM) are known to exert stimulating effect on the dendritic cell (DC) maturation. The aim of this investigation was a comparative study of the effect of different MAMs, used separately and in combination, on human monocyte-derived DC maturation in vitro. Methods. The studied MAMs were represented by lipopolysaccharide (LPS) from Escherichia coli and different biopolymers from Staphylococcus aureus Wood 46. DC phenotype was analyzed by flow cytometry. Functional maturity of DC was assessed in the mixed leukocyte reaction. Results. The use of MAMs in combination has been shown to be more efficient for phenotypic and functional maturation of monocyte-derived DCs than utilizing different MAMs separately. The most potent stimulatory effect has been observed for the combination of LPS with peptidoglycan (PepG) or teichoic acid with PepG. Conclusions. Combined use of different MAMs, especially those that activate different signaling pathways (LPS-PepG and teichoic acid-PepG), results in synergistic stimulation of monocyte-derived DC maturation.
\end{abstract}

Keywords: dendritic cells, lipopolysaccharide, teichoic acid, peptidoglycan.

Introduction. Dendritic cells (DCs) are highly specialized antigen-presenting cells (APC) that play a critical role in initiating primary $\mathrm{T}$-cell responses [1]. This function of DCs makes them attractive target cells for therapeutic intervention in different pathologic state, including inflammatory disease, cancer etc. A main approach for the DC therapeutic employment is DC vaccination $[2,3]$. Despite a wide use of DC vaccination in clinical trials, optimal conditions for the generation of functionally mature DCs remain to be established. To produce immature DCs (iDCs), monocytes are usually

(C) Institute of Molecular Biology and Genetics, NAS of Ukraine, 2012 incubated with granulocyte-macrophage colony-stimulating factor (GM-CSF) and interleukin-4 (IL-4). Because mature DCs (mDCs) are better than iDCs to the stimulation of cytotoxic T-cells, iDCs derived from monocytes are often treated with various exogenous stimuli known to induce DCs maturation [4-6]. Recent insight in DC biology has provided some guidelines concerning optimal approaches for generation of mature DCs ex vivo, aimed at elevation of DC migration ability after the administration to patients. These approaches are based on new data on the role of pattern recognition receptors (membrane-associated and cytoplasmic ones) in DC maturation. The recognition receptors 
recognize endogenous (danger-associated molecular patterns such as HMGB1 proteins) and exogenous (MAMs) agonists. Upon in vivo exposure to MAMs, immature DCs switch from antigen-capturing to antigenpresenting and T-cell-stimulating modes [7-10]. The culture of DCs in vitro with such compounds or their pharmacological analogs (such as the TLR4 ligand lipopolysaccharide (LPS), the TLR3 ligand polyinosinic:polycytidylic acid - polyI:C, the TLR9 ligand oligodeoxynucleotide containing one or more unmethylated $\mathrm{CpG}$ dinucleotides - $\mathrm{CpG}$ ODN, etc.) can induce the phenotypic and functional maturation of cultured DCs. It is important that the functional DC maturation could be noticeably augmented by the use of certain MAM combinations [11-14]. The aim of our work was to perform a comparative investigation on the effects of different biopolymers from Staphylococcus aureus Wood 46 used separately and in combination with LPS from Escherichia coli on maturation of human monocyte-derived DC (MDDC) in vitro.

Materials and methods. Generation of DCs. Monocyte derived DCs were generated from peripheral blood mononuclear cells (PBMCs) from 5 healthy blood donors, as previously described $[15,16]$. This study was approved by the local Ethics Committee. Peripheral blood samples were placed into heparinized tubes, and PBMCs were isolated by Ficoll-Verografin gradient centrifugation (density $-1.077 \mathrm{~g} / \mathrm{ml}$ ). After isolation, PBMCs were resuspended in RPMI-1640 medium («Sigma», USA) supplemented with $40 \mu \mathrm{g} / \mathrm{ml}$ gentamycine, seeded in 96-well tissue culture plates in the appropriate culture microenvironment, and left to adhere overnight at $37{ }^{\circ} \mathrm{C}$ in a humidified $5 \% \mathrm{CO}_{2}$ atmosphere. After the adherence period, non-adherent cells were removed. The adherent cells were then cultured in the appropriate medium supplemented with granulocyte colony-stimulating factor (G-CSF) $(1000 \mathrm{IU} / \mathrm{ml}$, «Grastim», Dr. Reddy's Laboratories Ltd., India) and $10 \%$ autologous serum. The culture medium was replaced every three days. On the $7^{\text {th }}$ day, MAMs were added into the cultural medium to induce terminal maturation of the generated DCs. On the $8^{\text {th }}$ day, at the end of culturing, the adherent cells were harvested by gently scraping with a cotton swab. The obtained mature DCs were washed in PBS without $\mathrm{Ca}^{2+}$ and $\mathrm{Mg}^{2+}$ and resuspended prior to immunophenotyping.
Treatment with MAMs. In our study, the following MAMs were used: LPS from E. coli («Sigma»); teichoic acid (TA) from $S$. aureus Wood 46, prepared as described earlier [17], peptidoglycan (PepG) and the extract of cytoplasmic membranes (CPM) from S. aureus Wood 46, kindly provided by professor V. Pozur. MAMs used separately and in combination were added on the $7^{\text {th }}$ day of DCs culturing at the concentration of $0.2 \mu \mathrm{g} / \mathrm{ml}$ for $24 \mathrm{~h}$. All MAMs were singly used at their maximal effective concentration determined by titration experiments $[18,19]$.

Flow cytometry analysis of DC phenotype. The generated DCs were washed twice with PBS w/o $\mathrm{Ca}^{2+}$ or $\mathrm{Mg}^{2+}$ and stained with mouse anti-human monoclonal antibodies (mAbs). We have used FITC-conjugated antibodies against CD86 («Dako», Denmark) and PEconjugated antibodies against HLA-DR («Sorbent», Russian Federation). After immunofluorescent staining, the cells were fixed with $1 \%$ paraformaldehyde and then analyzed by a FACS Calibur using CellQuest software («Becton-Dickinson», USA).

Allogeneic mixed leukocyte reaction assay. The DCs were harvested, washed and resuspended in RPMI$1640+10 \%$ fetal bovine serum. In total, $2 \cdot 10^{5}$ allogeneic T-cells were incubated with DCs (at the ratio 10:1) in 96-well flat-bottomed plates. Three days later, the cell cycle distribution of T-cells was analysed by FACS.

Apoptosis assay. T-cell death by apoptosis was assessed by the flow cytometry analysis of DNA content. Briefly, after incubation with DCs T-cells were washed twice with PBS, resuspended in ice-cold $70 \%$ ethanol with gentle vortexing to the final concentration of $1 \cdot 10^{6}$ cells $/ \mathrm{ml}$, and stored at $4{ }^{\circ} \mathrm{C}$ until analysis. Before quantification of DNA content, the T-cells were pelleted at $400 \mathrm{~g}$ for $5 \mathrm{~min}$, resuspended in PBS, pelleted again, and resuspended in $200 \mu \mathrm{l}$ PBS, $0.1 \%$ Triton X-100, $0.1 \mathrm{mmol} / 1 \mathrm{EDTA}$, and $50 \mu \mathrm{g} / \mathrm{ml}$ DNAse free RNAse («Stratagene», USA) with $5 \mu \mathrm{g} / \mathrm{ml}$ PI. The DNA content was analysed using a FACScan («Becton-Dickinson») with Cellquest acquisition and analysis software («Becton-Dickinson»). Cellular debris and doublets were excluded from the analysis by their forwardlight-scatter and right-angle-light-scatter properties.

Statistical analysis. The statistical significance of the data was determined by Student's $t$-test, the values $\mathrm{p}<0.05$ were considered as significant. 

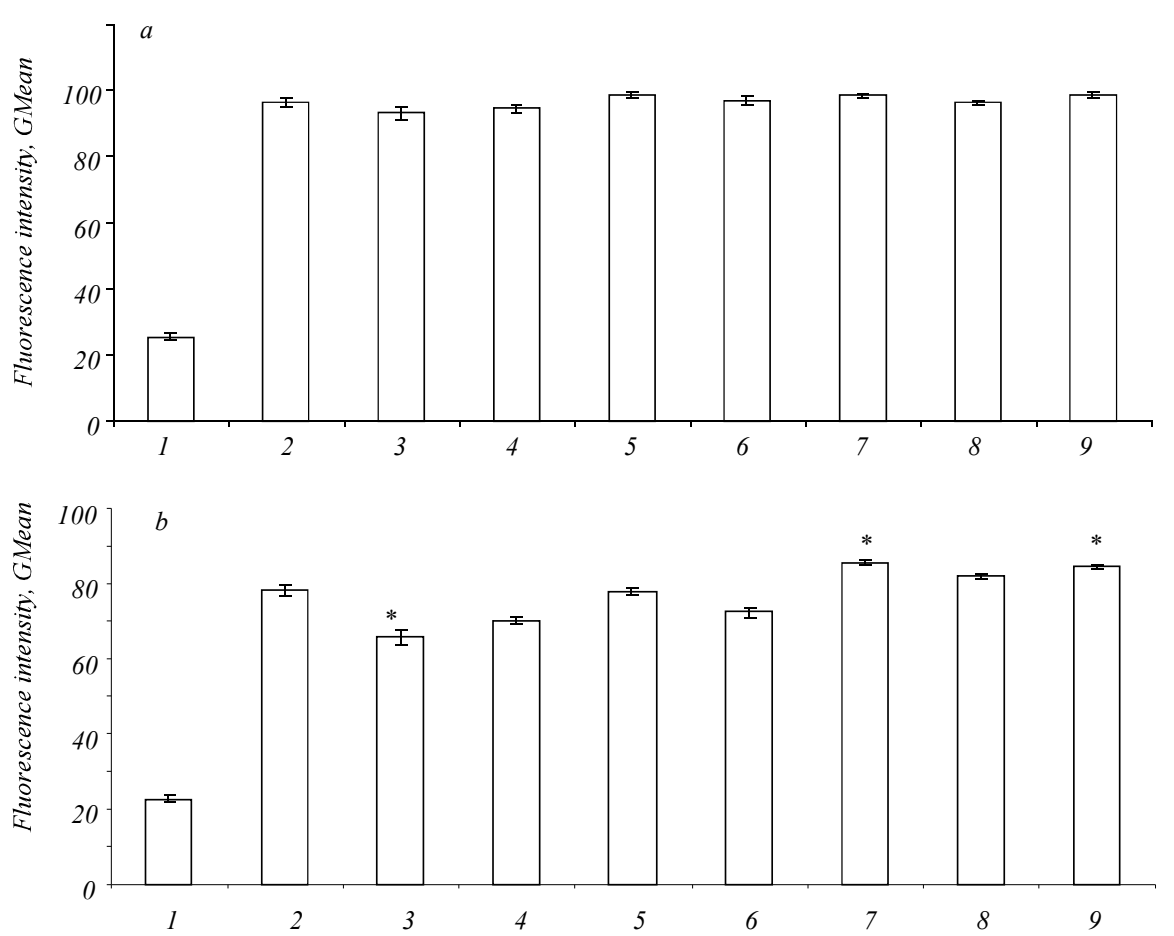

Fig. 1. Dendritic cells (DCs) treated with microbe-associated molecules show an increased expression of HLA-DR and CD86 molecules: $a$ - HLA-DR fluorescence intensity; $b-\mathrm{CD} 86$ fluorescence intensity ( 1 - isotypic control; 2 - control DC; 3 PepG-DC; 4 - TA-DC; 5 - CPM-DC; 6 LPS-CPM-DC; 7 - LPS-PepG-DC; 8 LPS-TA-DC; 9 - PepG-TA-DC); *p < $<0.05$ in comparison with control DC

Results and discussion. In our investigation we have used different MAMs that are recognized by TLR2/ TLR4 and are able to trigger MyD88 dependent signaling pathways, which lead to activation of NF- $\mathrm{\kappa B}$ and MAPK. We also have used PepG that are recognized by TLR2 and/or cytosolic sensors Nod1 and Nod2 associated with an adaptor molecule, RICK/Rip2/CARDIAK, through CARD-CARD interaction, which also leads to the activation of NF- $\mathrm{kB}$ and MAPK [20-22]. So, we intended to analyse whether the simultaneous activation of these signaling cascades would have a synergistic effect with respect to DC activation. To estimate a contribution of different bacterial polymers, used separately or in combination, to MDDC maturation, we have chosen the protocol of DC generation in vitro employing only G-CSF. The LPS-treated DCs that are conventionally used in clinical studies served as a control and were compared with DC treated with other MAMs separately or in combination [23].

So, MDDC underwent maturation as follows: 1) control-DC treated with LPS alone; 2) PepG-DC treated with PepG alone; 3) TA-DC treated with TA alone; 4) CPM-DC treatred with CPM alone; 5) LPS-CPMDC treated with LPS in combination with CPM; 6) LPS-PepG-DC or with LPS in combination with PepG; 7) LPS-TA-DC, treated with LPS in combination with
TA; 8) PepG-TA-DC treated with PepG in combination with TA.

MAMs induce DC with a mature phenotype. Firstly we have compared the effects of the different maturation stimuli on the DC phenotype. All maturation stimuli have led to generation of phenotypically mature DC, expressing co-stimulatory molecule CD86 and HLADR molecule (Fig. 1). However, among DCs matured in the presence of MAMs used separately the most effective stimulation of CD86 expression was observed in DCs treated with LPS and DCs treated with CPM (MyD88 dependent signaling pathway) (Fig. 1, $b$ ).

It is necessary to point out that combined MAMs were more effective for phenotypic maturation of MDDCs than separately used bacterial polymers, especially PepGTA-DC and LPS-PepG-DC. These data evidence to the synergistic effect of combined microbe-associated patterns activating different signaling pathways (MyD88 and RICK/Rip2/CARDIAK dependent signaling pathways).

MDDCs treated with TLR-agonists stimulate T-cell proliferation. The major function of DCs is their ability to trigger the activation and proliferation of T-cells. The mixed leukocyte reaction (MLR) was used as functional endpoint to assess the in vitro lymphocyte proliferation in response to DCs treated with the bacterial 

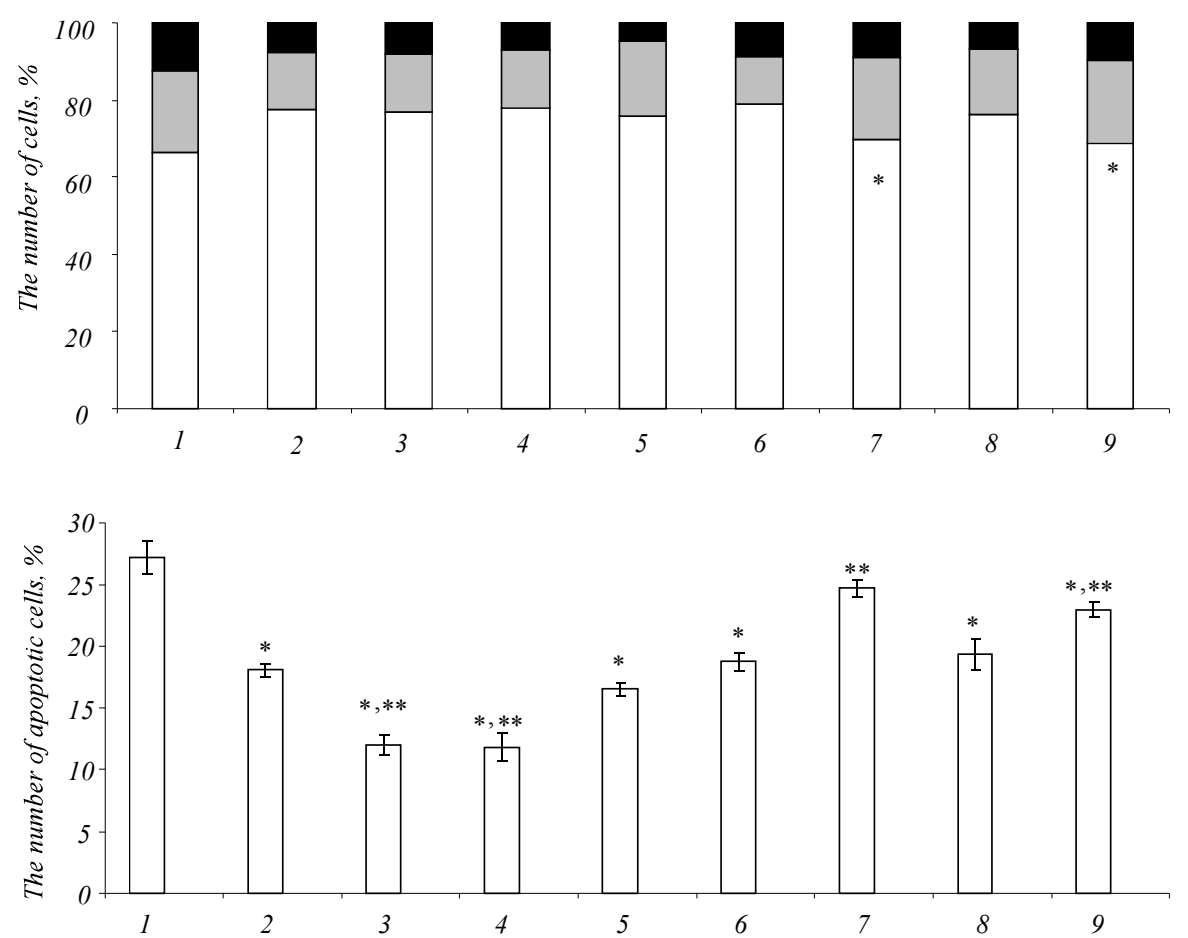

Fig. 2. The effect of dendritic cell (DC) matured with microbe-associated molecules on cell cycle distribution of allogeneic lymphocytes: 1 - positive control; 2 control DC; 3 -PepG-DC; 4-TA-DC; 5 CPM-DC; 6 - LPS-CPM-DC; 7 - LPSPepG-DC; 8 - LPS-TA-DC; 9 - PepGTA-DC. Lymphocytes stimulated with phytohemagglutinin were used as a positive control; $\mathrm{p}<0.05$ in comparison with control DC

\begin{abstract}
Fig. 3. Apoptosis level of lymphocytes in mixed leukocyte reaction with dendritic cell (DC), treated with different microbeassociated molecules and their combinations: 1 - positive control; 2 - control DC; 3 - PepG-DC; 4 - TA-DC; 5 - CPM-DC; 6-LPS-CPM-DC; 7 - LPS-PepG-DC; 8 LPS-TA-DC; 9 - PepG-TA-DC; ${ }^{*} \mathrm{p}<0.05$ in comparison with positive control; **p $<$ $<0.05$ in comparison with control DC
\end{abstract}

polymers indicated. DCs treated with MAMs and lymphocytes from allogeneic individuals were mixed in a one-way primary MLR and lymphocyte proliferation was measured by flow cytometry and estimated at a proliferative index (Fig. 2).

As it is shown in Fig. 2, DC treated with all indicated MAMs stimulated allogeneic lymphocytes proliferation, although in the probes with DC treated with bacterial polymers separately, the stimulation was less significant. The cell cycle distribution of allogeneic lymphocytes stimulated with PepG-DC, TA-DC, CPM-DC was similar to that in probes with control DC (DC treated with LPS). The proliferative index in these probes was at average $24 \%$. On the contrary, the cell cycle distribution of allogeneic lymphocytes stimulated with LPS-PepG-DC and PepG-TA-DC was more similar to that in positive control (lymphocytes stimulated with phytohemagglutinin). The mean value of proliferative index in these probes was $31 \%$. Increased proliferation of allogeneic lymphocyte stimulated with DC treated with combination of MAMs, have demonstrated that the observed synergy of combined bacterial polymers, especially those utilizing different signaling pathway, is related not only to phenotypic maturation of MDDC, but also to functional maturity of these cells.
An additional criterion of lymphocyte activation by MDDC, treated with MAMs, was apoptosis (activationinduced cell death) [24]. As it is shown in Fig. 3, the number of apoptotic cells in the positive control was 1.5 times higher than that in the control DC and CPM-DC probes.

In probes with $\mathrm{DC}$, treated with Pep-G and TA, apoptosis level was at average 1.5 times lower than that in the control DC probes and 2.28 times lower than that in the positive control.

The highest number of apoptotic cells was observed in probes with DC treated with LPS in combination with PepG and with TA in combination with PepG.

Conclusions. MAMs are known to exert stimulating properties toward DC. Here we have demonstrated a synergistic stimulating effect of combined use of different bacterial polymers in regard to MDDC maturation, especially high in the case of MAMs utilizing different signaling pathway. The synergistic effect of combined pattern recognition receptors triggering on MDDCs included an increase in the expression of costimulatory CD86 and HLA-DR molecules and stimulation of lymphocyte proliferation in mixed leukocyte reaction. These results might be helpful for the development of new protocol for in vitro DC generation in DC-based vaccination strategies. 
Л. М. Сківка, Ю. В. Швець, Н. М. Храновська, О. Г. Федорчук, В. В. Позур, Н. В. Сенчило

Синергічний вплив асоційованих з мікробами молекул на фенотипове та функціональне дозрівання дендритних клітин, отриманих $з$ моноцитів периферичної крові людини in vitro

Резюме

Відомо, щчо асочійовані з мікробами молекули (АММ) чинять стимулювальний вплив на дозрівання дендритних клітин (ДК). Мета. Провести порівняльне дослідження дії різних АММ, використаних як самостійно, так і в комбіначї̈, на дозрівання ДК, отриманих з моноцитів периферичної крові людини іn vitro. Методи. Як АММ застосовано ліпополісахарид Escherichia coli та біополімеpu Staphylococcus aureus Wood 46. Фенотипову зрілість ДК охарактеризовано методом проточної ичитофлуориметрії. Функияіональну зрілість ДК аналізували в реакиії змішаної культури лейкоцитів. Результати. Встановлено, щуо комбіноване використання АММ є більш результативним для стимуляції фенотипового і функиіонального дозрівання ДК іп vitro порівняно із самостійним застосуванням мікробних біополімерів. Найвиразніший стимулювальний ефект спостерігався за використання комбінаиії пептидоглікану з ліпополісахаридом та пептидоглікану з тейхоєвою кислотою. Висновки. Показано існування синергічного впливу АММ щзодо стимуляиії дозрівання ДК, особливо суттєвого у разі комбінованого застосування асоиійованих з мікробами молекул, які взаємодіють з ДК, активуючи різні сигнальні иляхи (пептидоглікан у поєднанні з ліпополісахаридом або пептидоглікан у поєднанні з тейхоєвою кислотою).

Ключові слова: дендритні клітини, ліпополісахарид, тейхоєва кислота, пептидоглікан.

Л. М. Скивка, Ю. В. Швец, Н. Н. Храновская, А. Г. Федорчук, В. В. Позур, Н. В. Сенчило

Синергическое влияние ассоциированных с микробами молекул на фенотипическое и функциональное созревание дендритных клеток, полученных из моноцитов периферической крови человека in vitro

\section{Резюме}

Известно, что ассоциированные с микробамими молекулы (АММ) окзывают стимулирующее действие на созревание дендритных клеток (ДК). Цель. Провести сравнительное исследование влияния различных АММ, использованных как самостоятельно, так и в комбинации, на созревание ДК, полученных из моноцитов периферической крови человека in vitro. Методы. В качестве АММ применяли липополисахарид Escherichia coli и биополимеры Staphylococcus aureus Wood 46. Фенотип ДК характеризовали методом проточной ичтофлуориметрии. Функциональную зрелость ДК анализировали в реакции смешанной культуры лейкоцитов. Результаты. Установлено, что комбинированное использование АММ является более результативным для стимуляцุии фенотипического и функционального созревания ДК іп vitro по сравнению с применением бактериальных биополимеров самостоятельно. Наиболее выраженный стимулирующий эффект наблюдали при использовании комбинации пептидогликана с липополисахаридом, а также пептидогликана с тейхоєвой кислотой. Выводы. Показано существование синергического стимулирующего влияния АММ на созревание ДК, наиболее выраженного при комбинированном использовании ассочиированных с микробами молекул, которые взаимодействуют с ДК, активируя различные сигнальные пути (пептидогликан в сочетании с липополисахаридом или пептидогликан в сочетании с тейхоевой кислотой).

Ключевые слова: дендритные клетки, липополисахарид, тейхоевая кислота, пептидогликан.

\section{REFERENCES}

1. Liu K., Nussenzweig M. C. Origin and development of dendritic cells // Immunol. Rev.-2010.-234, N 1.-P. 45-54.

2. Palucka A. K., Ueno H., Fay J., Banchereau J. Dendritic cells: a critical player in cancer therapy? // J. Immunother.-2008.-31, N 9.-P. 793-805.

3. Janikashvili N., Larmonier N., Katsanis E. Personalized dendritic cell-based tumor immunotherapy // Immunotherapy.-2010.2, N 1.-P. 57-68.

4. Castiello L., Sabatino M., Jin P., Clayberger C., Marincola F. M., Krensky A. M., Stroncek D. F. Monocyte-derived DC maturation strategies and related pathways: a transcriptional view // Cancer Immunol. Immunother.-2011.-60, N 4.-P. 457-466.

5. Jeras M., Bergant M., Repnik U. In vitro preparation and functional assessment of human monocyte-derived dendritic cells-potential antigen-specific modulators of in vivo immune responses // Transpl. Immunol.-2005.-14, N 3-4.-P. 231-244.

6. Gilboa E. DC-based cancer vaccines // J. Clin. Invest.-2007.117, N 5.-P. 1195-1203.

7. Jensen S. S., Gad M. Differential induction of inflammatory cytokines by dendritic cells treated with novel TLR-agonist and cytokine based cocktails: targeting dendritic cells in autoimmunity // J. Inflamm. (Lond).-2010.-7.-P. 37-48.

8. Seya T., Akazawa T., Tsujita T., Matsumoto M. Role of Toll-like receptors in adjuvant-augmented immune therapies // eCAM.2006.-3, N 1.-P. 133-137.

9. Hemmi H., Akira S. TLR signalling and the function of dendritic cells // Chem. Immunol. Allergy.-2005.-86.-P. 120-135.

10. Sato A., Iwasaki A. Induction of antiviral immunity requires Toll-like receptor signaling in both stromal and dendritic cell compartments // Proc. Natl Acad. Sci. USA.-2004.-101, N 46.P. 1624-1629.

11. Boullart A. C., Aarntzen E. H., Verdijk P., Jacobs J. F., Schuurhuis D. H., Benitez-Ribas D., Schreibelt G., van de Rakt M. W., Scharenborg N. M., de Boer A., Kramer M., Figdor C. G., Punt C. J., Adema G. J., de Vries I. J. Maturation of monocyte-derived dendritic cells with Toll-like receptor 3 and 7/8 ligands combined with prostaglandin E2 results in high interleukin-12 production and cell migration // Cancer Immunol. Immunother.-2008.-57, N 11.-P. 1589-1597.

12. Nguyen-Pham T. N., Lim M. S., Nguyen T. A., Lee Y. K., Jin C. J., Lee H. J., Hong C. Y., Ahn J. S., Yang D. H., Kim Y. K., Chung I. J., Park B. C., Kim H. J., Lee J. J. Type I and II interferons enhance dendritic cell maturation and migration capacity by regu- lating CD38 and CD74 that have synergistic effects with TLR agonists // Cell. Mol. Immunol.-2011.-8, N 4.-P. 341-347.

13. Warger T., Osterloh P., Rechtsteiner G., Fassbender M., Heib V., Schmid B., Schmitt E., Schild H., Radsak M. P. Synergistic activation of dendritic cells by combined Toll-like receptor ligation induces superior CTL responses in vivo // Blood.-2006.108, N 2.-P. 544-550.

14. Krummen M., Balkow S., Shen L., Heinz S., Loquai C., Probst $H$., Grabbe $S$. Release of IL-12 by dendritic cells activated by TLR ligation is dependent on MyD88 signaling, whereas TRIF 
signaling is indispensable for TLR synergy // J. Leukoc. Biol.2010.-88, N 1.-P. 189-199.

15. Khranovska N. Preparation strategy and therapeutic application results of a new generation autological dendritic cell-based anticancer vaccine // Oncology (Special issue).-2010.-12, N 1 (43).P. 134-139.

16. Khranovska N. M., Grinevich Yu. A. Preparation method of autological dendritic cell-based anticancer vaccines. Methodological recommendation.-Kyiv: Naukova dumka, 2006.-8 p.

17. Potebnya G. P., Skivka L. M., Pozur V. V., Rudik M. P., Senchilo N. V., Fedorchuk O. G., Khranovska N. M. Influence of teichoic acid from $S$. aureus on metabolic activity of macrophages and cytotoxic activity of splenocytes of mice bearing Lewis lung carcinoma // Exp. Oncol.-2008.-30, N 3.- P. 220-223.

18. Skivka L. M., Trompak O. O., Kudryavets Y. I., Bezdenezhnykh N. A., Susak Y. M. The effect of NSC-631570 (Ukrain) alone and in combination with pathogen-associated molecules on cell cycle distribution and apoptosis induction of mouse melanoma cells with different biological properties // Exp. Oncol.-2010.-32, N 2.-P. 92-96.

19. Pozur $V$. The effect of teichoic acid from Staphylococcus aureus Wood 46 on the dendritic cells maturation in vitro // Microbiol. Biotechnol.-2010.-4, N 12.-P. 66-72.
20. Kim H. S., Shin T. H., Yang S. R., Seo M. S., Kim D. J., Kang S. K., Park J. H., Kang K. S. Implication of NOD1 and NOD2 for the differentiation of multipotent mesenchymal stem cells derived from human umbilical cord blood // PLoS One.-2010.-5, N 10.-P. 15369.

21. Franchi L., ParkJ. H., Shaw M. H., Marina-Garcia N., Chen G., Kim Y. G., Nunez G. Intracellular NOD-like receptors in innate immunity, infection and disease // Cell. Microbiol.-2008.-10, N 1.-P. $1-8$

22. Kaisho T., Akira S. Regulation of dendritic cell function through Toll-like receptors // Curr. Mol. Med.-2003.-3, N 4.-P. 373385.

23. Jin P., Han T. H., Ren .J, Saunders S., Wang E., Marincola F. M., Stroncek D. F. Molecular signatures of maturing dendritic cells: implications for testing the quality of dendritic cell therapies // J. Transl. Med.-2010.-8.-P. 4-18.

24. Brenner D., Krammer P. H., Arnold R. Concepts of activated T cell death // Crit. Rev. Oncol. Hematol.-2008.-66, N 1.P. 52-64.

Received 10.05.11 